\title{
Congenital Dermal Sinus and Cyst in Adulthood
}

\author{
Aria Fallah, Abhishek Raut, Ryan Rebello, Kesava Reddy
}

Can. J. Neurol. Sci. 2009; 36: 114-116

Dermal sinus tracts are formed during the 26th day of gestation from the incomplete closure of cutaneous ectoderm from neural ectoderm. ${ }^{1-5}$ As remnants of incomplete neural tube closure, they are often associated with dermoid and epidermoid cysts, spinal cord tethering and spinal fluid drainage. ${ }^{1,2,6-8}$ As such, dermal sinus tracts are diagnosed during early childhood..$^{2,8}$ These entities most frequently present in the lumbosacral area and less commonly in the thoracic region. ${ }^{2,8-10} \mathrm{We}$ present a patient with a thoracic dermal sinus tract and an associated intradural dermoid cyst presenting in late adulthood.

\section{Case Report}

A 60-year-old gentleman presented with a chronic sinus tract and intermittent abscess formation in the mid-thoracic spine. Although the dermal sinus had been present for as long as the patient could remember, it remained asymptomatic until his 20 's. At that time, he developed an abscess and was treated with antibiotics for two to three weeks. The affected region demonstrated recurrent bouts of infection over the ensuing two to three years and again was treated with systemic antibiotics. The area was first excised by a general surgeon 11 years prior to presentation. Subsequently, he required additional surgical excisions on three separate occasions, none of which resulted in complete cessation of symptoms.

Between episodes, he remained healthy and asymptomatic. The patient's last flare-up occurred one year prior to the current presentation. At that time he became quite unwell and experienced intermittent fevers, generalized myalgias, anorexia, and fatigue. Treatment with ciprofloxacin $(500 \mathrm{mg}$ po bid) for one week provided no improvement. The area was incised and drained one liter of malodorous pus. Specimen cultures revealed nonspecific gram positive cocci and gram negative bacilli. He has remained relatively well since this incident.

Due to the recurrent nature of these infections, the patient underwent plain x-rays as well as ultrasound and was eventually referred to our neurosurgical service. Magnetic resonance study suggested an abnormality in the interspinous space of the T4-5 region with the findings being most consistent with a dermal sinus tract with an intradural dermoid cyst on the dorsal aspect of the spinal cord (Figures 1,2). No clear spinal cord tethering was noted though thecal sac appeared tented.

Preoperatively, the patient demonstrated no neurological abnormalities on examination. His comorbidities included wellcontrolled hypertension, surgically-treated carotid stenosis and hypercholesterolemia. At surgery, an elliptical incision encircling the sinus was made and the sinus tract was followed to the dura. Partial removal of T3 and T5 as well as complete removal of T4 laminae was performed. With the assistance of an intra-operative microscope, a midline dural incision around the

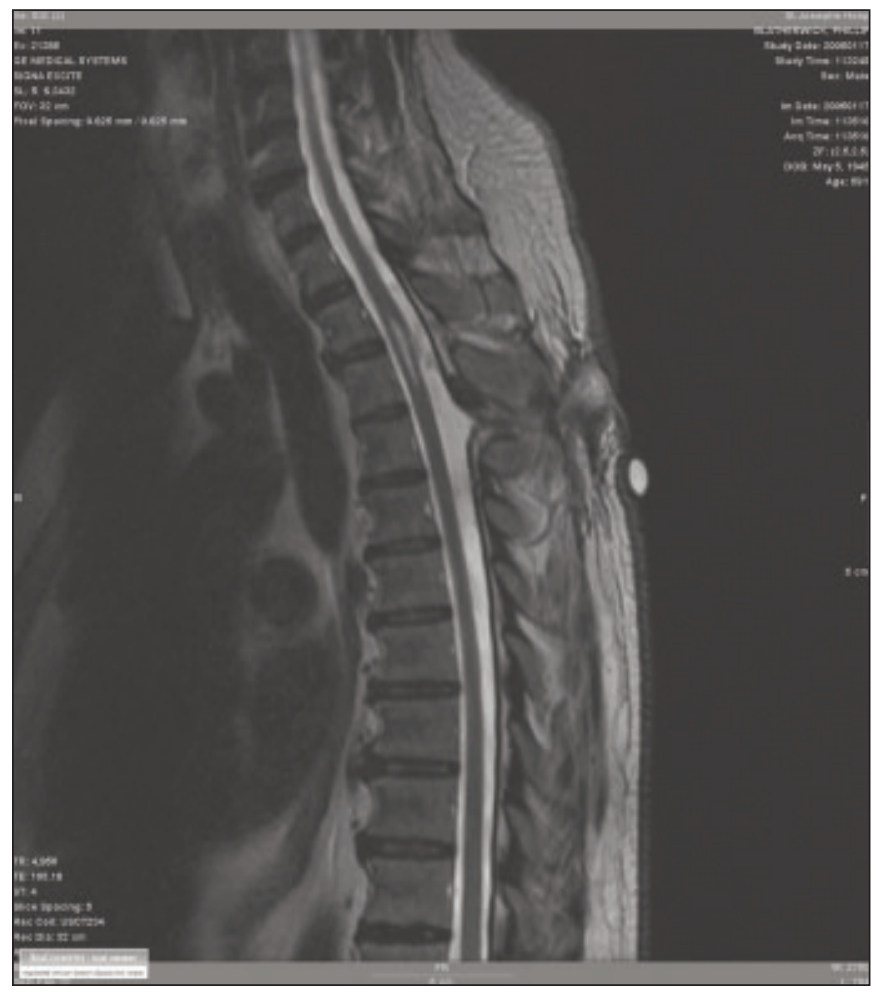

Figure 1: Sagittal T2 weighted image demonstrating the syrinx and the dermal sinus tract.

dermal sinus tract was made. The dura was opened and the dermoid cyst was dissected out. The cyst ruptured during the resection of the sinus and cyst and released opalescent fluid. The patient's post-operative course was uneventful and he was discharged one day after surgery. He remains well at 18 months follow-up.

Histopathological examination of the surgical specimen revealed a cyst lined by keratinizing squamous epithelium with

From the Division of Neurosurgery, McMaster University, Hamilton, Ontario, Canada. Received March 9, 2007. Final Revisions Submitted July 11, 2008. Correspondence to: Kesava KV (Kesh) Reddy, 66 Charlton Ave. West, Hamilton, Ontario, L8P 2C1, Canada. 


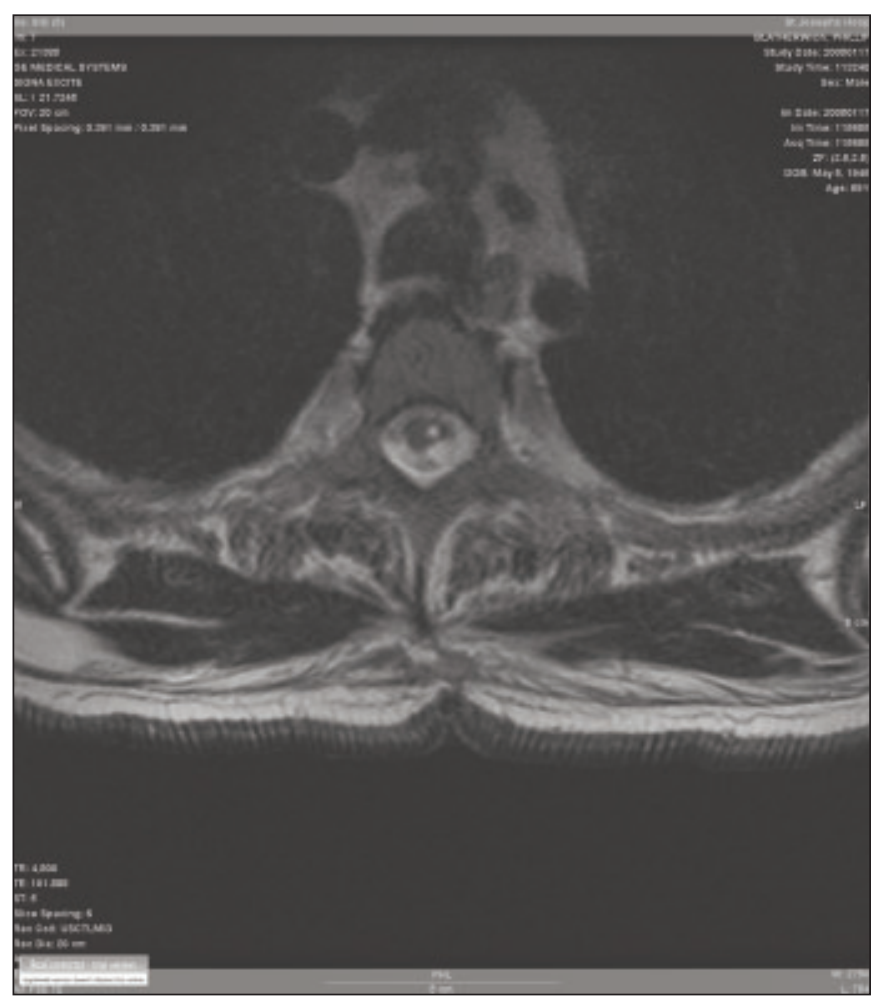

Figure 2: Axial T2 weighted image demonstrating the dermoid cyst. modality of choice is magnetic resonance imaging to demonstrate the extent of attachment, associated lesions and spinal dysraphism. ${ }^{1,2,4,7}$ The role of surgery is complete excision of the tract and management of intraspinal pathologies accordingly. ${ }^{1-3}$ The initial surgical excision has been shown to provide the highest rate of complete tract resection. ${ }^{1}$ Further surgical explorations are limited by the extent of local scarring. ${ }^{1}$ During the operative procedure, careful measures to excise any associated cysts without rupture is essential to prevent aseptic meningitis. , $^{6}$

Including this case report, six cases of adult spinal dermal sinus tracts have been published..$^{3,9,12-14}$ It is interesting to note that only one of the cases has occurred in a female patient. ${ }^{3}$ Dermal sinus tracts have not traditionally been described to preferentially arise in a particular gender. Congenital dermal sinus tracts have presented as late as 62 years-of-age. ${ }^{14}$ The average age of presentation in the pediatric population is ten years. ${ }^{2}$ Contrary to the pediatric literature in which a lumbar presentation is most common, adult spinal dermal sinus tracts have manifested equally in the thoracic, lumbar, and sacral regions. ${ }^{2,9}$

Presenting complaints were most commonly back pain and ranged from soft tissue swelling to recurrent sinus infections. Additionally, $50 \%$ of the cases were associated with pus drainage from the sinus tract. However, the commonly associated dermoid cyst was only observed in one case. Unfortunately, the postoperative course in these patients has been poorly reported with $50 \%$ of the cases having no followup data. To date, our patient represents the longest followup in the adult literature. The complications of post operative surgery and the recurrence rates of dermal sinus tracts are worth investigating in future cases. hair and sebaceous glands in its wall. The features of the specimen were consistent with a dermoid cyst (Figure 3). Histopathology of the surrounding sections was consistent with an excised dermal sinus tract.

\section{Discussion}

In 1934, Walker and Bucy were the first to coin the term 'congenital dermal sinus'. ${ }^{9,11}$ Since then, congenital dermal sinus tracts have been well described in the literature. They are rare entities that have been estimated to have an incidence of one in 2500-3000 live births. ${ }^{5,9}$ While dermal sinus tracts most commonly form in the lumbar region (40\%), cranial (10\%) and thoracic (10\%) involvements have been reported. ${ }^{2,9}$ Hyperpigmented patches, hair nevii or capillary angiomas may be found superficial to these tracts. ${ }^{7}$ Dermoid and epidermoid cysts may be associated with dermal sinus tracts occurring in approximately half of all cases. ${ }^{1,6,7}$ They form in the course of the tract and contain sebaceous glands and hair follicles. ${ }^{8}$

Presentation of a dermal sinus can range from asymptomatic to paraplegia or infection related mortality. ${ }^{1-3,9,11}$ Although the entity itself is benign in nature, patients can present with symptoms of neural compression or tethered cord syndrome secondary to an associated cyst.4,6,8 Major complications of dermal sinus tracts include intradural infections resulting in meningitis or intrathecal abscess formation. ${ }^{4}$ The diagnostic

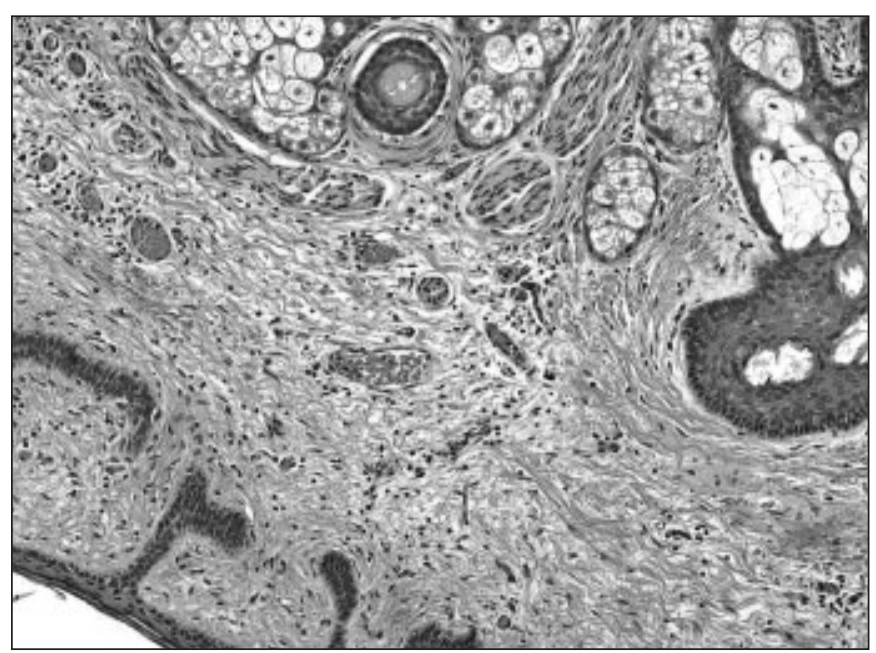

Figure 3: 100X power of a very small edge of the cyst lining which a keratinizing squamous epithelium, and a pilosebaceous unit in the wall of the cyst. 
Table: Current literature on adult spinal dermal sinus tracts

\begin{tabular}{l|l|l|l|l|l}
\hline $\begin{array}{l}\text { Author, } \\
\text { Year }\end{array}$ & $\begin{array}{l}\text { Age } \\
\text { (years), } \\
\text { Gender }\end{array}$ & Location & $\begin{array}{l}\text { Presenting } \\
\text { Complaint }\end{array}$ & Associated Features & $\begin{array}{l}\text { Postoperative } \\
\text { followup }\end{array}$ \\
\hline $\begin{array}{l}\text { Feely, } \\
1990-91\end{array}$ & 62, Male & Lumbosacral & $\begin{array}{l}\text { Drainage of } \\
\text { clear fluid }\end{array}$ & Hair tuft & Not available \\
\hline $\begin{array}{l}\text { Qasho, } \\
1998\end{array}$ & 44, Male & Lumbar & $\begin{array}{l}\text { Lower back pain } \\
\text { radiating to } \\
\text { groin }\end{array}$ & $\begin{array}{l}\text { Subcutaneous lump, } \\
\text { superior dimple, multiple } \\
\text { café-au-lait spots }\end{array}$ & Not available \\
\hline $\begin{array}{l}\text { Anzai, } \\
1998\end{array}$ & 21, Female & Sacral & $\begin{array}{l}\text { Soft-tissue } \\
\text { swelling in left } \\
\text { gluteal region }\end{array}$ & Fever, pus drainage & Not available \\
\hline $\begin{array}{l}\text { Alafaci, } \\
2000\end{array}$ & 52, Male & Sacral & $\begin{array}{l}\text { Back pain, leg } \\
\text { restlessness }\end{array}$ & $\begin{array}{l}\text { Hemangiomatous } \\
\text { discolouration, } \\
\text { pigmentation, } \\
\text { hyperthrichosis, purulent } \\
\text { drainage }\end{array}$ & $\begin{array}{l}\text { No recurrence at 1 } \\
\text { month }\end{array}$ \\
\hline $\begin{array}{l}\text { Kara, } \\
2003\end{array}$ & 37, Male & Thoracic & $\begin{array}{l}\text { Numbness, } \\
\text { muscle spasms } \\
\text { in right arm, } \\
\text { headaches }\end{array}$ & $\begin{array}{l}\text { Meningocele, disc } \\
\text { protrusion }\end{array}$ & $\begin{array}{l}\text { Seizures, weakness } \\
\text { of right arm and } \\
\text { neck at 6 months }\end{array}$ \\
\hline $\begin{array}{l}\text { Fallah, } \\
2008\end{array}$ & 60, Male & Thoracic & $\begin{array}{l}\text { Recurrent sinus } \\
\text { infections }\end{array}$ & $\begin{array}{l}\text { Dermoid cyst, purulent pus } \\
\text { drainage }\end{array}$ & $\begin{array}{l}\text { No recurrence at } \\
18 \text { months }\end{array}$ \\
\hline
\end{tabular}

We describe an unusual adult presentation of a thoracic dermal sinus tract associated with an intradural dermoid cyst. The patient presented with repeated infections over decades, eventually culminating in a resection of the tract. A dermal sinus tract is an important diagnosis to be considered with repetitive midline infections even in adulthood. Aggressive surgical management is indicated to prevent serious neurological sequelae.

\section{REFERENCES}

1. Elton S, Oakes WJ. Dermal sinus tracts of the spine. Neurosurg Focus. 2001;10(1):A4.

2. Jindal A, Mahapatra AK. Spinal congenital dermal sinus: an experience of 23 cases over 7 years. Neurol India. 2001;49: 243-6.

3. Anzai S, Yamaguchi T, Takasaki S, Kurata S, Takayasu S. Tethered cord associated with intraspinal lipoma and a subcutaneous abscess secondary to a dermal sinus. Int J Dermatol. 1998; 37(1):77-8.

4. Ansari S, Dadmehr M, Nejat F. Possible genetic correlation of an occipital dermal sinus in a mother and son. Case Report. J Neurosurg. 2006;105(Suppl 4):326-8.

5. Costa JM, de Reina L, Guillen A, Claramunt E. Occipital dermal sinus associated to a cerebellar abscess. Case. Neurocirugia (Astur). 2004;15(5):480-3.

6. Higashi S, Takinami K, Yamashita J. Occipital dermal sinus associated with dermoid cyst in the fourth ventricle. AJNR. 1995;16(Suppl 4):945-8.

7. Barkovich AJ, Edwards M, Cogen PH. MR evaluation of spinal dermal sinus tracts in children. Am J Neuroradiol. 1991;12(1): 123-9.

8. Morandi X, Mercier P, Fournier HD, Brassier G. Dermal sinus and intramedullary spinal cord abscess. Report of two cases and review of literature. Childs Nerv Syst. 1999;15(4):202-8.

9. Kara NN. Spinal congenital dermal sinus associated with upper thoracic meningocele: a case report. Neurosurg Focus. 2003; 15(1):ECP2.

10. Rastogi H, Behari S, Phadke RV, Gupta RK, Kumar S, Mitral P. Spinal segmental maldevelopment with a dermal sinus. Neuroradiology. 1996;38(7):658-60.

11. Chen C-Y, Lin K-L, Wang H-S, Lui T-N. Dermoid cyst with dermal sinus tract complicated with spinal subdural abscess. Pediatr Neurol. 1999;20(2):157-60.

12. Alafaci C, Salpietro FM, Grasso G, Collufio D, Caruso G, Morabito A, et al. Lumbosacral congenital dermal sinus presenting in a 52year-old man. Case report. J Neurosurg Sci. 2000;44(4):238-42.

13. Qasho R, Lunardi P, Lo Bianco FM, di Stefano M. Rare combination of spinal lesions and subcutaneous meningioma in a 44-year-old man. J Neurooncol. 1998;38(1):77-82.

14. Feely MP, Levy WJ, Schreiner M. Congenital dermal sinus presenting in a 62-year-old-man. Pediatr Neurosurg. 19901991;16(4-5):258-9. 